\title{
Reactualization of the Pancasila Law Ideals in the Flow of Globalization
}

\author{
Achmad Irwan Hamzani ${ }^{1}$, Mukhidin ${ }^{2}$, Sanusi $^{3}$, Havis Aravik ${ }^{4}$ \\ \{al_hamzani@upstegal.ac.id ${ }^{1}$, mukhidin@upstegal.ac.id ${ }^{2}$, sanusi@upstegal.ac.id ${ }^{3}$, \\ havis@stebisigm.ac.id $\left.{ }^{4}\right\}$ \\ Faculty of Law, Pancasakti University, Tegal-Indonesia ${ }^{1,2,3}$, STEBIS-IGM, Palembang-Indonesia ${ }^{4}$
}

\begin{abstract}
The ideals of Indonesian law are rooted in Pancasila. The founders of the State of the Republic of Indonesia established Pancasisla as the foundation of the philosophy of statehood. The of the Pancasila law ideals will reflect the goals of the country. The aim of the study was: to describe Pancasila in the legal order in Indonesia, the need for the reactualization of the Pancasila law ideals in the development of national law. The nature of the research study is normative, the philosophical approach, using secondary data, and the data will be analyzed qualitative. The results of this study indicate that Pancasila in Indonesian legal order was placed as the source of all legal sources. This is in accordance with the Preamble of the 1945 Constitution, and Law of the Republic of Indonesia Number 12 Year 2011 about Establishment of Legislation. Pancasila is a source of material legal legislation. National law which became the ideals of the Indonesian nation rooted in Pancasila as a view of life. Pancasila is essentially a legal ideal as an embodiment of the ideals of the Indonesian state that will become a guiding star in the development of national law. The of the Pancasila law ideals will give birth to the Pancasila legal system. The of the Pancasila law ideals are the ideals of a legal system rooted in a distinctive national culture that contains a prismatic concept. Development of national law will intersect with global developments. With the continuing realization of the Pancasila law ideals, the resulting legal products still reflect the personality of the Indonesian nation but are also adaptive to legal developments in a global context.
\end{abstract}

Keywords: reactualization, law ideals, Pancasila, globalization

\section{Introduction}

Pancasila is the source of all legal sources in legal development in Indonesia. The Indonesian nation to date is still proceeding to develop a national legal system. The national legal system that is expected to be in the future is a legal system that is extracted from the Indonesian people's views contained in the Pancasila. Each principle contains fundamental values and becomes five operational principles in the development of practical law. The unity of the five precepts embodies a value system that can be elaborated into the national legal system.

The legal aspirations of the Indonesian people are of the Pancasila law ideals. In micro terms, the of the Pancasila law ideals are laws that summarize all values, concepts, interests in a bond of prismatic law by taking the best elements of Indonesian legal awareness. In macro terms, of the Pancasila law ideals must also pay attention to the legal dynamics globally, especially international conventions while still filtering them first. 
The profile of the national legal system in the future is expected to illustrate the ideals of the Indonesian people contained in the Preamble of the 1945 Constitution. A legal system oriented to moral religious, humanistic, nationalistic, democratic, and social justice. The national legal system will be a reference and basis for the motivation of the state ruler to run the constitution of an independent Indonesia to achieve the highest good (summum bonum) in a state and nation [1].

The of the Pancasila law ideals is a legal system rooted in a distinctive national culture that has existed for a long time and is practiced in cultural values and order [2]. The legal system must be in accordance with the distinctiveness of the cultural roots of each nation. Because the law has the duty to serve the community, the legal system must also be as unique as the cultural roots of the people it serves. The Pancasila legal system is a legal system that is unique to Indonesian society.

An ideal country does not simply import its legal system. If the applicable legal system is not rooted in its culture, then the law becomes foreign in its acceptance and implementation. At present, the prevailing legal system in Indonesia still inherits the Dutch colonial legal system which clearly has different cultural roots. Even in some respects it is contrary. Historically, the Dutch enforced the civil law that they brought to build the state legal ideology in the midst of various legal values that had previously developed in the lives of Indonesian people which of course were very different [3]. For example lifestyle, the Indonesian people always prioritize mutual cooperation, togetherness, and prioritizing family. The Dutch, on the other hand, have an individualistic lifestyle, tend to formally solve all problems.

Law in a country is strongly influenced by the development of the nation's soul (volkgeist). Even in the discourse on the development of legal theory, there is one school of law that recognizes how important the legitimacy of the living law as stated by Carl Von Savigny, "the law was not made but grew with the community". Roscoe Pound (1870-1964) also legitimized legal interdependence on non-legal elements. According to him, the interests of the state, social interests and personal interests can cause the law to not always be dogmatic.

Departing from this, the concept of the Pancasila law ideals in the development of law in Indonesia has become important, especially in actualizing it in the midst of legal dynamics. Pancasila as the basis of the country on the one hand, and the philosophy of life of the nation and state of Indonesia on the other hand, must always be explored in order to be able to answer the demands of the times. The purpose of this study is: to describe the position of Pancasila in the development of national law, describe the profile of the Pancasila law ideals, and the reactualization of the Pancasila law ideals in the flow of globalization.

\section{Research Methods}

This research is a type of normative legal research. Normative legal research is doctrinal legal research or theoretical legal research. It is called normative legal research because because what is examined is the law of the theoretical or normative aspects, not to review the applied aspects or their implementation. The approach used is philosophical. A philosophical approach is an approach that views law as an ideal set of values, which should be a reference in the formation, regulation and implementation of law. A philosophical approach is used because this study is ideal by using a legal philosophy perspective that views law as law in 
ideas. The data used is secondary data. Secondary data is data that is not obtained by researchers directly or originating from other parties in the form of written documents. The researcher obtained data through searching library materials online. The data collected will be analyzed qualitatively. Qualitative data analyst is a form of analyst by interpreting and describing data through words in a narrative with scientific logic.

\section{Discussion}

\subsection{Pancasila Position in Legal Development in Indonesia}

Pancasila in the Indonesian legal order is placed as the source of all legal sources. This is in accordance with the Preamble of the 1945 Constitution which places Pancasila as the basis of the state . It was also stated in the Law of the Republic of Indonesia Number 12 Year 2011 about the Establishment of Article 6 Laws and Regulations that Pancasila is the source of all legal sources. According to this provision, Pancasila is placed as a basic norm or rule (Grundnorm, Basic Norm). Pancasila by itself is a source of material law from written law, which among others is in the form of legislation from the highest to the lowest levels [4].

Placement of Pancasila as an opening in the 1945 Constitution is the foundation of philosophy that underlies and animates the preparation of the provisions stipulated in the constitution. Pancasila underlies and oversees the life of the state in Indonesia, including the management and implementation of its legal politics. The preparation and application of legal procedures in Indonesia must also be based on Pancasila. It is not permissible in an Indonesian country which is based on the philosophy of Pancasila, the practice of administering its country is contrary to the values of Pancasila [5].

Pancasila is also a view of the Indonesian nation's life formulated in five precepts. Each principle contains fundamental values and becomes five operational principles in the development of practical law. The unity of the five precepts embodies a system of values that can be elaborated into the legal system. Five precepts are the main joints of Pancasila, namely the One and Only God, just and civilized humanity, Indonesian unity, popularism led by wisdom in deliberation / representation, and social justice for all Indonesian people. All are listed in the 4th paragraph of the Preamble of the 1945 Constitution. The values that exist in Indonesia, such as nationalism, socialism and Islam, fill the Pancasila. Upholding, inheriting, civilizing and preserving the fundamental values of nationality and state of Indonesia in the precepts of Pancasila is the obligation of all infrastructure and superstructure in the jurisdiction of the Republic of Indonesia .

The Indonesian state is building towards a modern country. The function of law in modern society is a means of integrating mechanisms of interests, both cultural, economic, political, individual, social and state interests. Law must come forward in giving direction to renewal. Law as a means of renewing society is based on the assumption that the existence of order in the renewal business is an absolute necessity. All thoughts about law must be linked to the basic framework of national development .

The role of law is becoming increasingly important in order to realize development goals. The function of law in development is not just a social control tool. Law can move the community to behave according to new ways in order to achieve the desired state of society. The function of law as a means of renewing society is that law is used to direct the community to certain patterns as desired by creating new patterns. There are things that must be 
maintained and protected, and on the other hand the law is needed to create patterns that are in accordance with development and so that changes caused by development run in an orderly and orderly manner.

The values that are used as joint guidelines in all aspects of national life are formulated in a forum or institution called national law. The existence of legislation or law has the same mission, namely to regulate the order of life of humanity for the sake of the realization of the benefit of life and inner happiness. The realization of Pancasila in the field of law must produce provisions of legal provisions imbued or colored by the Pancasila. The whole legal system as a system of positive legal rules which is the elaboration or application of Pancasila in the field of law, can be called the Pancasila Law.

In full, Pancasila must be seen as a national guideline, as a national standard, norm and principles, which also contains human rights and human responsibility. Pancasila must also be seen as a margin of appreciation (boundary or line of appreciation) towards a pluralistic living law in society (the living law). The benchmark refers to the content of Pancasila values .

The implementation of legal development must be able to utilize Pancasila as a paradigm. The emphasis on development must rest on the universal ethics contained in its precepts, namely:

1. It must not conflict with the principles of the One Godhead who respect the order of religious life, religious sense and religion as a big interest.

2. Respecting the values of human rights both political, political, economic, social and cultural and within the framework of relations between nations that must respect the right to development.

3. Basing national unity on the appreciation of the concept of "civic nationalism" which appreciates pluralism.

4. Respect indices or "core values of democrasy" as a "democrating audit" tool.

5. Placing "legal justice" in the framework of "social justice" and in the relationship between nations in the form of the principles of "global justice".

Law as a regulation of human actions made by power is not only a decision. Legal implementation must be in accordance with the ideology of the nation concerned as protector. Human dignity must be taken as a person with the possibility of developing himself [6]. Indonesia has chosen the welfare state as a form of state. Every action and consequence must be based and resolved according to the law. It was stated in the Preamble of the 1945 Constitution that: "The government protects all nations and all bloodshed, advances public welfare and educates the life of the nation [7].

One thing that must also be emphasized in the development of national law is the creation of the rule of law and the enforcement of human rights, as well as the establishment of a national legal system that reflects truth, justice, accommodating, and aspirations. In other words, the creation of law enforcement regardless of one's position, rank and position for the supremacy of the law and the creation of respect for human rights.

\subsection{Profile of the Pancasila Law Ideals}

The law ideals (rechtsidee) mean that in essence the law as a rule of public behavior is rooted in the ideas, feelings, intentions, inventions and thoughts of the society itself [8]. Pancasila is the essence of law (rechtsidee) as the embodiment of the ideals of the Indonesian state (staatsidee) [9], which will become a guiding star (leitstern) for the Indonesian nation in 
the development of national law. It is this law that will give birth to the Pancasila legal system. The legal system that installs signs and gives birth to prosecutors' rules in national legal politics, namely the prohibition of the emergence of laws that are contrary to the values of Pancasila [5].

Pancasila as a legal ideal appears in the Preamble of the 1945 Constitution as a unified and rounded unity of the five precepts, namely the One Godhead, just and civilized humanity, Indonesian unity, popularism led by wisdom in deliberation / representation, and social justice for all people of Indonesia. The Pancasila Spirit as the basic value of animating the torso of the 1945 Constitution and other laws and regulations that apply in Indonesia [10]. The development of national law is essentially to build order concepts that are oriented to the values of Pancasila, namely:

First, religious morality (Godhead). The development of national law that is oriented to religious moral values in the context of the relegious nation state, does not control a particular religion (because it is not a religious state) [11], where noble moral values that have been grounded in Indonesia must be used as a basis for formulating national legal policies. The teachings of religion, especially Islam, which has been practiced in social life has been going on for centuries. This means that noble moral values that are rooted and grounded in Indonesia are characterized by transcendent religious values. There are no noble values of Pancasila that clash with the teachings of Islam. The inclusion of tauhid values in the ideology of the Indonesian nation does not make Muslims fight other people. Conversely, Muslims highly respect and respect other religious people [12].

Second, humanistic (humanity). The development of humanitarian-oriented national law means that all Indonesian human groups are in essence a degree of equality originating from a common ancestor, namely the descendants of Prophet Adam. Policies in the development of national law must be based on equality values among citizens. There is no minority tyranny and majority hegemony. All citizens have the same position before the law regardless of ethnicity, race and religion. There is no virtue of one group over another, except only taqwanya to God Almighty. Pancasila is an international universal value across all world state systems, accommodating a variety of systems and values of humanity in modern global society [13].

Third, nationalism (unity). The development of national law oriented to unity has the understanding that efforts to realize Indonesian national law must consider the unity and unity of the nation, avoid the slightest opportunity for the emergence of national disintegration. For example Muslims who, after independent Indonesia, immediately formed or merged into the nation of Indonesia [14]. That is, Muslims prioritize Indonesian nationalism rather than group egos. The destructive attitude of mutual destruction is an attitude that is far from Islamic values [12].

Fourth, democracy (populist). The development of national law oriented to popular democracy is understood to be that efforts to realize Indonesian national law must go through various stages of systematic and structured discussion based on consensus agreements. National law is an embodiment of values that are believed, respected and obeyed by the people or the Indonesian people, then the policy in giving birth to national law must depart from the will and agreement of the people democratically.

Fifth, social justice. The development of national law oriented to social justice is understood that the values of substantive justice must be reflected in every national legal policy. This justice covers various aspects of people's lives, both in the economic, sociocultural, and political fields. Legal development that is oriented to the values of justice and prosperity will give birth to inner and outer welfare for the people or the Indonesian nation. 
Legal development also builds a legal system which includes the development of legal material, legal structures including law enforcement agencies, legal facilities and infrastructure. The goal is to create a society that has a high awareness and legal culture in order to realize a legal state; and the creation of a just and democratic society [15].

With a framework of views on the ways in which human beings exist, the of the Pancasila law ideals are core:

1. Belief in the one and only God.

2. Respect for human dignity.

3. Nationalism and insight into the archipelago.

4. Equation and feasibility.

5. Social justice.

6. Moral and noble character.

7. Participation and transparency in the process of making public decisions [8]

Law is essentially a product of the valuation of reason rooted in human conscience about justice with regard to human behavior and human life situations. The appreciation of justice raises the judgment that in certain social situations people ideally behave in certain ways. The law inspired by Pancasila is a law based on the spirit of harmony. Harmony is the principle of propriety. The principle of propriety as a principle on how to conduct inter-community relations in which citizens are expected to behave in a manner that is in accordance with the reality of social reality. Community members are also expected to pay attention to appropriateness, that is, from the community members are expected to behave in such a way that they do not demean themselves and / or others .

Another characteristic that characterizes of the Pancasila law ideals is the principle of harmony. This principle requires the implementation of harmony in social life. Problem solving is a concrete problem, besides having to be based on the consideration of the truth and rules of the applicable law, it must also be accommodated in the social process as a whole as a whole by considering the views that live in the community.

The principle of harmony and principle of harmony as a characteristic feature of the Pancasila law ideals can be covered by one term, namely the nature of kinship. The of the Pancasila law ideals is the law of zeal for family. The spirit of family refers to an attitude based on the personality of every citizen, recognized and protected by society.

The of the Pancasila law ideals are ideals of a system rooted in a distinctive national culture. The law is not in a vacuum but is in the community with its distinctive cultural roots. Because the law has the duty to serve the community, the legal system must also be as unique as the cultural roots of the people it serves. The Pancasila lawl system is a legal system that is unique to Indonesian society which contains a prismatic concept [14].

Prismatic conception appears in four ways; First, Pancasila contains a good element from the view of individualism and collectivism. It is acknowledged that humans as individuals have basic rights and freedoms but at the same time attach to them basic obligations as creatures of God and as social beings. Secondly, Pancasila integrates the concept of the law state "Rechtsstaat" which emphasizes civil law and legal certainty and the conception of the rule of law "the Rule of Law" which emphasizes the common law and sense of justice. Third, Pancasila accepts the law as a tool of social reform (law as a tool of social engineering) as well as a mirror of a sense of justice that lives in society (living law). Fourth, Pancasila adheres to the notion of a religious nation state, not a religious state, but also not a religion (a secular state). The state must protect and foster all believers . 
Thus, as a conception of the prismatic Pancasila contains good and appropriate elements with distinctive values of Indonesian culture that have lived in the community for centuries. Customary law [16] and religious law that grow from and within the Indonesian environment also as part of national law.

\subsection{Reactualization of the Pancasila Law Ideals in the Flow of Globalization}

The of the Pancasila law ideals must be actualized so as not to lose direction and dissolve in the vortex of globalization. The legal order that operates in a society is basically the embodiment of the legal ideals adopted in society into various sets of rules and their enforcement. The law is an idea, intention, creativity and thought regarding the law or perceptions of the meaning of the law which cores on three elements; justice, usability, and certainty. The law will function as a general principle that will be used as a guideline, evaluation rules, and motivating factors in the administration of law . The existence of legal ideals will facilitate the translation into various sets of rules and facilitate the maintenance of consistency in law enforcement. The ideal legal system is the implementation of legal ideals in various legal principles and rules arranged in a system.

Pancasila as the ideal of law means being located as a fundamental norm of the state (staatsfundamentalnorm) in an Indonesian state that has constitutive and regulative functions. As a constitutive function, Pancasila determines the basis of a legal order. Whereas as a regulative function, determining positive law is fair or not. As a staatsfundamentalnorm, Pancasila is a measure of derivation (source of translation) of the legal order in Indonesia and the source of all laws and regulations in Indonesia [17]. Pancasila for the Indonesian nation itself is a view of life that describes the Indonesian nation's view of the relationship between humans and God, humans and fellow humans, as well as humans and the universe, which cores beliefs about the place of individual humans in society and the universe.

The of the Pancasila law ideals rooted in the Pancasila view of life will automatically reflect the state's goals and basic values listed in the Preamble, Trunk and Explanation of the 1945 Constitution. The Pancasila view of life is formulated in the five principles which become operational principles in legal development. The unity of the five fundamental values together with the various values outlined, embodies a system of values, and is elaborated into various legal principles and legal norms which all embody a legal system. Every legal rule reflects or is imbued with a value, and the legal system reflects or contains a value system.

The system can be divided into the value of the basic value and the value of the goal. Basic values as a foundation and reference for achieving or fighting for something. The value of the goal is something that must and should be fought for or realized. Pancasila is a "basevalues" and at the same time is a "values". The overall values in the Pancasila value system are united by the principle of "Unity in Difference" and "Difference in Unity" which animates the basic structure of human existence in togetherness, where all the behavior of the people and the state must refer to the Pancasila [8].

The unifying principle in the symbol of the state of the Republic of Indonesia is formulated in the expression "Unity in Diversity", which expresses the Indonesian nation's perspective from Sabang to Maraueke about the place of individual humans in society and the universe. These expressions contain recognition and respect for individual human dignity, the distinctiveness of existing regional ethnic groups and religious beliefs in the unity of nation and state .

According to the perspective of the understanding of the rule of law and the philosophy of life of the Indonesian people, the interests of individuals and the interests of the people are 
placed in a balanced position. This benchmark is used considering that the life in the Pancasila is full of life based on the existence of dialogue, deliberation and consensus. The Indonesian nation is not priori rejecting or a priori accepting foreign cultures entering Indonesia. These cultures are accepted as long as they do not conflict with Indonesian national culture, and conversely will enrich and strengthen or strengthen the existing culture. Of course to be accepted must go through a process of assessment and screening with a measure of Indonesia's own national culture, namely Pancasila .

Community structure can be an obstacle in terms of facilitating the means of social institutions that allow the law to have its form. Law is seen as an autonomous institution. As Eugen Ehrlich once stated that "... both now and at any time, the center of activity and the development of law is not in legislation, not in law, nor in court decisions, but in society itself". Society as the center of legal development is the forerunner to the birth of a law.

All social changes that occur in society are instruments that can influence the center of activity and legal development. Law continues to develop from time to time as problems arise in society. The concept of the rule of law that currently dominates also does not appear suddenly, but through a historical process. Law is closely related to social change, even as a reflection of fulfilling social needs .

There is a saying about the societas ibi ius which means that there is a society, there is a law, so that it reflects the relationship of social change and legal change. Society exists and creates laws, society changes, laws change. Legal changes through two forms; the community changes first, then the law comes to ratify that change (passive change), or law as a tool to change in a better direction (law as a tool of social engineering) .

Every nation and civilization also has its own unique character. This character is formed based on the history and cultural development of the community. Every nation has its own character and quality which is intrinsically not superior and imperial. The same thing happened to the formation of the law which has a close relationship with the culture of the community .

Products from national law development ideally give birth to laws that reflect national character. Indonesian characters strongly uphold religious values, moral norms, kinship, deliberation, mutual cooperation, tolerance and so on. The process of making legal products, the full participation of social groups or individuals in the community also provides a large role. This is as a consequence that Indonesia uses the mechanism of democracy as a political system so that it opens opportunities for public participation in determining policy. Legal products must be responsive in character, not a legal product that reflects the wishes of the government [18].

As a legal state, Indonesia must dynamically regulate human needs so that harmony is always maintained, at least there are mechanisms for resolving conflicts. The law produced must also be clear, firm and regulate the interests of the community. Legal material must contain the values of justice for the realization of public welfare [19].

The development of the national legal system certainly cannot be separated from changes in the order of life of the community both nationally and globally. The legal products produced must also reflect the life of the community itself, also adaptive to changes in law globally, so that the resulting legal products describe social phenomena [15].

Indonesia uses a modern legal system, but the legal system used is not from the Indonesian people themselves, but transplants from the outside (Dutch colonizers). The structure of legal institutions such as values, justice, roles and organizations, is also not from within as local genius. Modern law applied in Indonesia with its elements is a legal 
development that grows and develops in Europe. Whereas law in Europe has developed for decades as a social process in line with the development of its society .

Development of national law will intersect with global developments. The challenge of globalization can threaten the existence of the nation's personality. The Indonesian nation must not lose its identity in its legal style. With the continuing realization of the Pancasila law ideals, the resulting legal products still reflect the personality of the Indonesian nation but are also adaptive to legal developments in a global context.

The bitter experience of colonialism certainly cannot be repeated. But keep in mind that at this time the faces of colonialism and imperialism are no longer in physical form, but in other forms such as mastery of politics, culture, economics as well as law. The dominance of mainstream politics, culture, economy and law from foreigners will have the same impact as colonialism in the past, and even more will have an impact on the life of the nation, including in its legal development.

The Indonesian people certainly do not need to close themselves from the outside world because they can be left behind by the progress of the times and the progress of other nations. Because famous countries close themselves to the outside world such as the socialistcommunist state of Russia and China cannot survive and open themselves up. Legal development must make the nation and people of Indonesia also have to open up.

By continuing to do reactualization of the Pancasila law ideals will be able to filter so that only the cultural values and in accordance with national identity are absorbed. On the contrary, cultural values that are not suitable especially damaging the values of the national culture must be rejected, with the concept of Pancasila prismatic as a view of life and the foundation of the state and the of the Pancasila law ideals.

\section{Conclusion}

Based on the discussion above, it can be concluded that Pancasila in the Indonesian legal order was placed as the source of all legal sources. This is in accordance with the Preamble of the 1945 Constitution, and the Law of the Republic of Indonesia Number 12 Year 2011 about the Establishment of Legislation Article 6 that Pancasila is the source of all legal sources. Pancasila as the foundation of philosophy that underlies and animates the preparation of the provisions of the provisions contained in the constitution, and becomes a source of material law for legislation from the highest to the lowest levels. Pancasila is essentially a legal ideal as an embodiment of the ideals of the Indonesian state that will become a guiding star in the development of national law. The of the Pancasila law ideals will give birth to the Pancasila legal system, namely the legal system that places signs and gives birth to guiding rules in national legal politics. The Pancasila spirit as a guide to animating the torso of the 1945 Constitution and other laws and regulations that apply in Indonesia. The of the Pancasila law ideals are the ideals of a legal system rooted in a distinctive national culture that contains the concept of prismatic, which contains good and appropriate elements with distinctive values of Indonesian culture. Customary law and religious law that grow from and within the Indonesian environment as well as part of the national legal system. The of the Pancasila law ideals must be actualized so as not to lose direction and dissolve in the vortex of globalization. Development of national law will intersect with global developments. The challenge of globalization can threaten the existence of the nation's personality. The Indonesian nation must not lose its identity in its legal style. With the continuing realization of the Pancasila law 
ideals, the resulting legal products still reflect the personality of the Indonesian nation but are also adaptive to legal developments in a global context.

Acknowledgments. Our great appreciation goes to the Directorate of Research and Service to Society of the Ministry of Research and Technology and Higher Education of the Republic of Indonesia, who have provided funding in this study.

\section{References}

[1] R. S. Manurung, "NILAI HUKUM INDONESIA PREAMBLE TO THE 1945 CONSTITUTION : ANALYSIS OF POLITICAL VALUES AND VALUES OF INDONESIAN LAW,” J. IUS, vol. VI, no. 1, pp. 74-89, 2018.

[2] D. A. Hartanto, "Implementasi Nilai Filosofis Pancasila dan Agama Islam dalam Menangkal Paham Radikalisme di Indonesia,” Fikri, vol. 2, no. 2, pp. 307-344, 2017.

[3] A. Halim, "Teori-teori Hukum Aliran Positivisme dan Perkembangan Kritik-kritiknya," J. AsySyir'ah, vol. 42, no. 2, pp. 387-408, 2008.

[4] F. S. Pahlevi, "REVITALISASI PANCASILA DALAM PENEGAKAN HUKUM YANG BERKEADILAN DI INDONESIA,” J. Justicia Islam., vol. 13, no. 2, 2016.

[5] Tongat, "PANCASILA SEBAGAI DASAR FALSAFAH NEGARA DAN MAKNA FILOSOFISNY A DALAM PEMBAHARUAN HUKUM PIDANA NASIONAL," $M M H$, vol. 41, no. 3, pp. 399-406, 2012.

[6] P. Burlian, "Hakikat pembangunan hukum dan pertanggungjawaban hukum dalam payung pancasila perspektif islam," pp. 143-165.

[7] O. Sukmana, "Konsep dan Desain Negara Kesejahteraan (Welfare State)," J. Sospol, vol. 2, no. 1, pp. 103-122, 2016.

[8] A. Ibrahim, "PERSPEKTIF FUTURISTIK PANCASILA SEBAGAI ASAS / IDEOLOGI DALAM UU KEORMASAN," vol. III, no. 2, pp. 129-148.

[9] M. B. Sabon, “Aspek epistemologi filsafat hukum indonesia 1,” pp. 16-17, 1988.

[10] Sunaryo, "GLOBALISASI DAN PLURALISME HUKUM DALAM PEMBANGUNAN SISTEM HUKUM PANCASILA,” MMH, vol. 42, no. 4, pp. 535-541, 2013.

[11] K. Roisah, “( Kajian terhadap Hukum Kekayaan Intelektual ),” pp. 622-630, 2006.

[12] F. Fuad, "ISLAM DAN IDEOLOGI PANCASILA, SEBUAH DIALEKTIKA," Lex Jurnalica, vol. 9, no. 3, pp. 164-170, 2012.

[13] M. S. Itmam, "HUKUM ISLAM DALAM PERGUMULAN POLITIK HUKUM NASIONAL ERA REFORMASI."

[14] O. M. Mahfud, "Politik Hukum Dalam Perda Berbasis Syari ’ ah,” pp. 1-21.

[15] I. Y. Isdiyanto, "Menakar 'gen' hukum indonesia sebagai dasar pembangunan hukum nasional," J. Huk. Pembang., vol. 48, no. 3, pp. 589-611, 2018.

[16] S. Sudaryatmi, "Peranan hukum adat dalam pembangunan hukum nasional di era globalisasi," 1945.

[17] Sudjana, "Hakikat Adil Dan Makmur Sebagai Landasan Hidup Dalam Mewujudkan Ketahanan Untuk Mencapai Masyarakat Sejahtera Melalui Pembangunan Nasional Berdasarkan Pancasila," J. KETAHANAN Nas., vol. 24, no. 2, pp. 135-151, 2018.

[18] P. J. Setyowati, "Fungsi filsafat, agama, ideologi dan hukum dalam perkembangan politik di indonesia," Yuridika, vol. 31, no. 1, pp. 82-107, 2016.

[19] Y. Suhardin, "Peranan Hukum Dalam Mewujudkan Kesejahteraan Masyarakat," J. Huk. Pro Justitia, vol. 25, no. 3, pp. 270-282, 2007. 